\title{
Balancing the Conflict between Right to Information and Right to Privacy under Sri Lankan Fundamental Rights Perspective
}

\section{Vishaka Sooriyabandara}

University of Sri Jayewardenepura, Gangodawila, Nugegoda. vishaka06@yahoo.com

\begin{abstract}
Protecting the peace and human wellbeing of a particular society is the main purpose of existing a law. However, it is problematic to say exactly whether the real purpose of law can be achieved through the established law enforcement approaches like legislations, judgments, standing orders, circulars, regulations etc. Thus, to create a most effective legal system, finding an answer to that issue is very essential, because if the real purpose of law cannot be achieved properly from these approaches, other solutions should be found out to protect peace and human wellbeing of society.

Human rights are the universally accepted rights which should be granted to each and every person to color-up their public and private lives. Right to information and right to privacy takes a vast attention nowadays though they make a continuous conflict with the development of the modern communication technology, because when right to information attempts to provide maximum public information to get an extensive knowledge on the public sphere, right to privacy attempts to conceal one's personal information like family life, relationships, physical and mental integrity, etc. from others. It points out that both rights are very essential to properly arrange people's public and private lives.

Although Sri Lankan current legal system shows a satisfactory movement in protecting right to information, such a movement cannot be seen to protect people's privacy rights. Sure enough, in spite of having vast numbers of black and white written laws, an effective practical enforcement of those laws also cannot be seen. Thus, enforcing the protection of both right to information and right to privacy effectively and striking a balance between these two conflicting rights to prevent overlapping is essential to establish the real purpose of existing a law in Sri Lanka.
\end{abstract}

Keywords: Human Rights, Fundamental Rights, Right to Information, right to Privacy, Good Governance

\section{Objectives}

- Survey the public attitude towards right to information and the right to privacy and the importance of providing constitutional safeguards to these rights. 
- Identify the political and legal obstacles to encapsulate the above rights to Fundamental Right chapter of the constitution and evaluate measures that can be taken to remove these obstacles.

- Identify measures to develop the political and legal system in the country in reflection of provisions in internationally recognized Human Rights Treaties and Instruments.

- Suggest reforms for the existing framework in contemplation of frameworks of other countries.

- Compromise the mutual conflict between aforementioned two rights in order to enhance the transparency and the good governance and finally for the preservation of individual freedom.

\section{Research Question}

Here, to achieve these purposes, this research mainly seeks an answer to whether Sri Lankan legal system can effectively balance the protection of right to privacy and right to information. My hypothesis is however that Sri Lankan legal system has not succeeded in balancing the protection of these couple of rights.

\section{Methodology}

\section{Data Collection}

For the purpose of obtaining effective findings, gaining the support of both theoretical and practical aspects of the particular area is very essential. Thus, this article can be considered as an outcome of a field survey, as well as a library research.

To obtain general and specialized views on Sri Lankan protective standards of right to privacy and right to information, the ideas of general public and political / legal professionals have been taken into account. The sample was selected randomly in the variety of their occupation, hometown, gender, age and their level of education. The ideas of general public are obtained quantitatively by giving questionnaires and the ideas of political and legal professional are taken qualitatively by interviewing them. However, for the convenience of this research, it was limited to 20 participants.

However, one cannot come to a proper conclusion by only depending on a small field research. Further, the support of theoretical and scholar ideas are very important in giving better recommendations. Thus, the support of 
libraries and internet cannot be disregarded. There, the primary sources like legislations and judgments, as well as the secondary sources like books, dictionaries, encyclopedias, law reviews, journal articles, newspapers have also been referred.

\section{Data Analysis}

As mentioned in above paragraphs, referring only scholar ideas may not give a practical end to an issue. Because of being a social issue, the ideas of general public have a similar validity as experts' ideas. However, in this research, a special attention has been paid to realize various experiences of the participants which have been involved to colour their ideas.

In addition to that, the participants' admirations and criticisms on the role of ICT law in Sri Lankan employment sector are analyzed, as well as their suggestions are taken into account. The reasons which they gave to prove their ideas are also considered. Anyhow, the analysis is conducted by comparing the relevant theoretical ideas which have been published by national and international scholars, because sometimes, peoples' ideas should be shaped for proper governance.

\section{Literature Review}

\section{Right to Information}

"Freedom will be bereft of all effectiveness if the people have no access to information. Access to information is basic to the democratic way of life. The tendency to withhold information from the people at large is therefore to be strongly checked."'

Information is defined as the data and facts needed in day to day life. ${ }^{2}$ The need of this right is considered as prevalent from the early ages. In the modern world, the right to information is recognized as a basic human right. Sweden is the first state in recognizing this right which was in 1760.

In Asia, "financial crisis of the late 1990s led to the enactment of the Right to Information law and Fiscal Responsibility law in many Asian emerging market economies in order to tame (what Adam Smith called) the "animal spirits" of the newly industrializing countries such as Indonesia, Malaysia, Thailand, et al.," In Sri Lanka also, partial privatization of state-owned enterprises such as Sri Lanka Telecom, Sri Lankan Airlines and the Ceylon Gas Company, as well as the $1.5 \%$ negative economic growth in 2001 pointed out the essentiality of establishing the protection of right to information throughout the country. 
The concept of 'good governance rests with three pillars such as transparency, accountability and access to information. Thus, absence of even one single pillar can downfall the expected quality of good governance.

"Accountability and transparency can only be tested and challenged if the public have free access to information. One must know the rationale and reasoning upon which an administrative decision was taken if such decision affects him. The Authority refusing such information must justify it on grounds laid down by law. However the right to information is not available for the mere asking, it has to be restricted to persons who are affected by an order or decision of a public officer. Information cannot be sought by an inquisitive 'busybody' who is not affected. One cannot for example seek information as to why his neighbor was refused a building permit, or a liquor license."4

In the absence of information the public will not be able to challenge decisions taken against them personally or in respect of matters of public interest which affect them as a member of the public.

\section{Right to Privacy}

The right to privacy as an independent and distinctive concept originated in the field of tort law, under which a new cause of action for damages resulting from unlawful invasion of privacy was recognized. ${ }^{5}$ Elsewhere, in legal systems based on Roman Dutch Law, a right to privacy gained recognition as an independent personality right within the concept of dignitas. ${ }^{6}$

Universal Declaration of Human Right (UDHR) ${ }^{7}$ was the first attempt to formulate a right to privacy as a separate fundamental right, distinguishes the concept of 'privacy' (or private life) from a private sphere comprising family, home and correspondence. Accordingly, International Covenant on Civil and Political Rights $\mathrm{Act}^{8}$ is based on it, protects 'privacy', 'family', 'home', and 'correspondence' from 'arbitrary' or 'unlawful' interference, and recognizes that everyone has the right to the protection of the law against such interference. European Convention for the Protection of Human Rights and Fundamental Freedom (ECHR) ${ }^{9}$ and American Convention on Human Rights $(\mathrm{ACHR}){ }^{10}$ prefer the term 'private life' to 'privacy', while the former also substitutes 'family life' for 'family'. The French texts of the particular Articles of ICCPR and ECHR both use the expression vie priv' ee, suggesting that the terms 'privacy' and 'private life' are interchangeable. The concept also protects an individual from 'unlawful attacks' on his 'honor' and 'reputation', and recognize the right to protection of the law against such attacks.

The notion of privacy, according to the Human Rights Committee, refers to the sphere of a person's life in which he/she can freely express his or her 
identity, be it by entering into relationships with others or alone. ${ }^{11}$ The concept is included these ingredients.

- Protection against unlawful and arbitrary interference to oneself or to his/her family

- Privacy of personal information

- Freedom from arbitrary Search and surveillance

- Privacy of human relationship

- Privacy of Physical and moral integrity

- Privacy of personal identification

- Privacy of personal choice

- Privacy of private communication written communication, telephone conversation etc.

- Protection against unlawful attacks on his/her honor and reputation

\section{Results and Findings}

The Need of Balancing People's Right to Information and Privacy Rights

The previous discussion clearly points out that right to information and privacy rights are both complement and conflict with each other. By depending on the facts and circumstance of each case, it mostly seems the overlapping of the particular rights leading to potential conflict. "Both rights provide an individual access to his/her own personal information from government bodies, and privacy laws allow for access to personal information held by private entities. They also mutually enhance each other: privacy laws are used to obtain policy information in the absence of right to information law, and such laws are used to enhance privacy by revealing abuses." 12 It proves therefore that balancing the both rights is essential for a proper and better protection of human rights. Both rights are internationally recognized human rights with long histories and important functions. ${ }^{13}$ Under human rights law, typically no right is accorded a greater weight than another.

Sri Lankan Legal and Political Attitude towards the Right to Information and Right to Privacy

The democratic socialist republic of Sri Lanka, by its name, indicates the appreciation of establishing democracy and social welfare throughout the country. Also, it seems that the current Sri Lanka has paid much attention to 
establish good governance in the state. Therefore, discussing the taken stepst to protect right to information and right to privacy would not only supportive to answer our research question, but also to measure the standard of Sri Lankan democracy and good governance.

Constitution is the main piece of law of a modern sovereign state. From the vast number of human right clauses, one state can chose some rights for its members to enjoy. The Fundamental Right Chapter of states' Constitution is included by those chosen human rights. However, the Fundamental Right Chapter of Sri Lanka ${ }^{14}$ intimated that neither right to privacy nor right to information has been constitutionally guaranteed. However, with the implementation of Nineteenth Amendment to the Constitution, Sri Lankans have the right of access to any information held by any ministry, department or statutory body which is governed under local or provincial law, or any local authority or, any other person. ${ }^{15}$ Accordingly, one can within one month's time, file a fundamental right petition to the Supreme Court if there is an infringement or imminent infringement of his/her right of access to information by an executive or administrative authority.

Sure enough, the newly passed Right to Information Act $^{16}$ can be taken as a recent development of this area. The Act not only enforce people's right to information, ${ }^{17}$ but also it prevails over other written law. ${ }^{18}$ There, if the disclosure of information is denied by the public authorities, the aggrieved party is within the capacity of making an appeal to the "Right to Information Commission." Due to the existence of these useful provisions, the Act has brought Sri Lanka to the third place in protecting people's right to information. ${ }^{19}$

Apparently, it seems that the Act has somewhat attempted to protect privacy rights through the Part of 'Denial of Access to Information', because the limitations stipulated in the Act include that the denial to access information may arise the personal information in concern has no public activity or interest, ${ }^{20}$ as well as it limits providing medical records unless consented and permitted to by the person in question. ${ }^{21}$ However, above limitations could be avoided where the request of information is very much urgent and as per severe circumstances surrounding the necessity of such information. ${ }^{22}$ In concern of Sri Lankan legal context, the judiciary has played a significant role to establish the right to information by extending interpretation of the freedom of speech and expression entrenched in Article 141 (a) of the Constitution through series of decisions. However, taking a deferent view, Fernando v. SLBC, ${ }^{23}$ states that "Freedom of Speech does not include right to information but can include a participatory listener's right". In Channa Pieris v. $A G^{24}$, it was held that the right to information refers to the freedom of the public to know the truth. Also, in Environmental Foundation v. $U D A^{25}$, it was emphasized that right of the public for information about transactions of the public funds and usage of 
common natural resources. It indicates the concept of state accountability and good governance, transparency and protection of human dignity.

In Sri Lanka, right to privacy is protected only as a delictual matter under the concept of Actio Injuriarum. Hence, unlike right to information which is concerned as a public law issue, protection of right to privacy is concerned as a private law issue and it is completely developing by case laws. In Nadaraja v. Obeysekara, ${ }^{26}$ the tern 'invasion of privacy' was discussed. There, it was recognized that there is an individual space for every person. Thus, according to the case, prevention of others' interference (orally or, in writing or, by action) to that individual space is the purpose of existing a privacy law. It was however decided that privacy rights are somewhat diminished when people are in public place

As a state party to the United Nation, Sri Lanka can get the influence of the united nation international conventions. Accordingly, due to the given protection to these two rights by Universal Declaration of Human Rights (UDHR) ${ }^{27}$ and the International Covenant on Civil and Political Rights (ICCPR) ${ }^{28}$, Sri Lanka can obtain such protection vaguely.

In addition to that, recognition and protection of family as the basic unit by Sri Lankan state ${ }^{29}$ shows the room to protect people's privacy rights

\section{Analysis}

In spite of passing the Nineteenth Amendment enforced the protection of right to information, not only not constitutionally guarantying the right of privacy, but also not having even a judicial interpretation on that right indicates the state's lack of concern in protecting the privacy right. Consequently, Constitutional entrenchment of right to information only, without right to privacy has been resulted number of social issues.

Further, more than 90 countries around the world have entrenched right to information constitutionally and most of them have recognized right to privacy also. It denotes that nowadays many countries considered that protecting these rights which are like two facets of a coin with cautious balance is necessarily important.

Though the state of Sri Lanka obtained the appreciation of international community by enacting the Right to Information Act, vast number of its conflicts has been criticized by political and legal scholars. For example, archaic acts, such as the Establishments Code $^{30}$ and the Press Council Law ${ }^{31}$, continue to be in force. The existence of such Acts restricts the scope of the new Act in place and limits the public access to the benefits afforded in terms of Section 2 and 3 of the Right to Information Act. One such important Act 
that needs to be brought to attention is the Official Secrets Act No. 32 of 1955. The existence of this Act restricts access to documents that are confidential and documents that contain very sensitive information. In addition to that, Lack of penalties for non-compliance and exemption of economic information can also be taken as weaknesses of this Act.

Even so, as mentioned in above paragraph, not having a proper statute has downgraded the protection of the right to privacy.

Nonetheless, in Canadian legal system, two mutually-distinguish legislations called Access to Information $\mathrm{Act}^{32}$ and Privacy $\mathrm{Act}^{33}$ deal with right to privacy and information where the former one elaborates on information accessible to the public. Section 69 (1) keeps the national security and foreign affairs away from the scope of the acts. Here, an independent office named Information Commissioner has been created to ensure the proper regulation of important information.

In 2005, India has voted for the Right to Information $\mathrm{Act}^{34}$ and recognized the right to information. Further, state institutions are prevented from revealing any information in violation of any one's human rights.

Above all, positively, "the Act would restructure the transparency of the government and public authority dealings. Thus, the instances in which the public being blindfolded in times of corruption will be limited, and the Act will further provide the public with an avenue to raise their dissenting views and concerns of the same." ${ }^{35}$ It had been professionally noted that the Act has wellsucceeded over the particular Act in India. "Since the RTI law was introduced, India has seen an improvement in governance, dissemination of information and involvement of civil society in the governance process ${ }^{936}$ Hence, the Act will be a monitor for showcasing the reality, whilst making the latent motives of a government accessible to the public to some extent ${ }^{37}$.

Apparently, with regard to the particular judicial decisions, law is silent on what type of information that can be accessed by public, methodology to be used and limitations available in access to them. These perplexities of law may result publishing of officially protected and sensitive information in the name of the right to information. The state officers and institutions hold the responsibility of the information may undergo with many issues. On the other hand, many issues have been emerged regarding the transparency of some sate activities since information that needs to be exposed to the public, are concealed using the quilt of state secrecy and right to privacy.

Even though the previous chapter has pointed out the judicial protection of bot rights, a negative aspect is also there to be discussed. The negative aspect of it is the absence of a proper mechanism to protect the party jeopardized as a 
result of revelation of their personal information. There is an inherent risk with disperse of extremely public sensitive information and the maximum remedy available for such victim is to file a defamations case and claim compensation which may not necessarily reimburse the damage caused.

In Victor Ivon v. Sarath N. Silva ${ }^{38}$ and Sunila Abesekara v. Ariya Rubasinghe ${ }^{39}$ it was proclaimed that right to information must not be considered in isolation but fusion with other human rights. Accordingly, right to information needs to be limited as long as publicizing information harms wellbeing of the public. However, it is noteworthy that right to privacy has not been expressly identified as a basic human right in any of these judgments and if possible, it would be a golden milestone in the history of court of justice.

Also, the Indian Supreme Court recognized the right to privacy in Kharak Singh v. State of Uttar Pradesh ${ }^{40}$ and declared that even the state cannot obtain one's personal information without reasonable grounds.

Unfortunately, though Sri Lankan state recognizes and protects family as a basic unit of the country under the Constitutionalized Derective Principles of State Policy, no person ca enforce that issue by filing a petition to any court of law or a tribunal. ${ }^{41}$ Therefore, one cannot say that Sri Lankan Constitution has effectively recognized the privacy rights of people.

Although Sri Lanka is a member state to United Nations, because of being a duelist state, such international Conventions like ICCPR are not legally enforcing in the country. A legislation should be passed by expressly mentioning the clauses to enforce them legally. Anyhow, though the Parliament passed ICCPR Act ${ }^{42}$ to enforce ICCPR in Sri Lanka, in the Act, neither right to privacy nor right to information has been mentioned to be protected.

Apparently, insufficient protection of right to privacy and right to information can be a dangerous cause of declining other human rights like freedom of expression, right to family life, right to equality and non-discrimination etc. thus, it intimates that weak protection of those rights makes a possibility of violating fundamental rights. European Union has recognized that 'Everyone has the right to freedom of expression. This right shall include freedom to hold opinions and to receive and impart information and ideas without interference by public authority and regardless of frontiers. ${ }^{43}$

However, as stated in the previous chapter, taking a deferent view towards the connection between freedom of expression and right to information, the Supreme Court held in Fernando v. SLBC, ${ }^{44}$ that there is no right to information as such, but that the right was ancillary to give effective meaning to the petitioner's freedom of speech. In that case, the petitioner was attacked by a guess speaker in a program broadcasted by SLBC. Though the petitioner 
asked SLBC to visit the subsequent program to express his position as a reply to the said guess speaker, SLBC terminated the program. Therefore to exercise his right to reply which is protected under freedom of expression, he claimed the right to information in respect of the speech made by his opponent. He stated that this right entitled him to tape recording or transcript of the program in which he was attacked.

According to the Supreme Court decision, Article 14 (1) (a) of the Constitution is not to be interpreted narrowly. Not only does it include every form of expression, but its protection may be invoked in combination with other express guarantees (such as the right to equality) photographs and the like and arguably it may even extend to a privilege not to be compelled to disclose sources of information, if that privilege is necessary to make the right to information "fully meaningful". Likewise, other rights may be needed to make the actual exercise of the freedom of speech effective: rights in respect of venues, amplifying devices, etc. Here, Fernando, J. has stated that "I doubt, however, that it includes the right to information simplicity."

In the same manner, right to privacy can be also emphasized by protecting the right to life, liberty and security. It can be proved by the series of judicial decisions given by United States' Indian, Canadian etc. courts. According to them, although the right to privacy, as such, had not been identified under the constitution, it was implicit in the right to 'life' and 'personal liberty' guaranteed to the citizens of that country and could not, therefore, be curtailed 'except according to procedure established by law. ${ }^{45}$ Unfortunately, due to not recognizing the right to life, liberty and security by the Constitution, these ideas cannot be practically implementing in Sri Lanka.

Right to information is said to be obtained in two ways. The first way deals with a person's right to receive information which is either related to or necessary for the exercise of his own freedom of speech. ${ }^{46}$ However, Fernando v. SLBC, shows that Sri Lankan judges has reluctant to apply this on their judgments. Sure enough, the cases that fall into the second way have upheld the right for receive information on the basis of constitutional provisions which is expressly recognize that right and are therefore, not helpful ${ }^{47}$.

The whole discussion clearly points out that the Sri Lankan legal regime has not paid sufficient attention in protecting people's privacy rights. Only few number of delictual case laws have given a minimum support to develop the rights. It dangerously influence not only for the people's personal and family life, but also his/her professional life. Not having a proper data protection law has created a vulnerable situation in Sri Lankan industrial field especially in a situation where information and communication technology is playing a major role. As a result, this loophole seems as a very bad issue in collapsing 
the whole, economic, political, social and legal system.

On the other hand, not having a proper balance of these two rights makes the situation worse. Taking measures to protect right to information in a state not having a proper privacy law cause serious violation of privacy rights. The invers proportional nature of the two rights is the main reason for that. Sure enough, the data analysis of the field survey revealed that most legal and political professionals are reluctant to realize the inseparable connection between right to information and privacy rights, because of the conflict between public law and private law. As aforementioned, right to information is concerned as an area of public law, whereas right to privacy is concerned as an area of private law. However, the dangerous impact of the said private law concept to the foundation of Sri Lankan socio economic political system has just discussed in the previous paragraph. Thus, rejecting the connection between the two rights due to their conceptual nature cannot be accepted.

\section{Recommendation}

To minimize the aforementioned disadvantages, the below mentioned suggestions may be useful. It should be also mentioned that the analysis of both field survey and the academic research were equally important to make these recommendations.

\section{Minimize the weaknesses of protecting right to information}

It is true that current Sri Lanka has a better protective mechanism of right to information, but minimizing the previously mentioned weaknesses would also make it even better. Thus, seeking a transparency of the newly established 'Right to Information Commission' is essential. Moreover, declaring a broad judicial interpretation on the Fundamental Right Chapter is also important.

\section{Effective establishment of right to Privacy}

Every now and then, the whole discussion proved that Sri Lanka has very much low consideration on protecting right to privacy. To establish democracy and good governance effectively, giving a more concern to that is also essential. Thus,

- Constitutionally protecting right to privacy

- Enacting necessary legislation to enforce privacy and data protection

- Holding a more judicial concern on protecting right to privacy

may help to treate right to privacy as equally as other recognized human rights. 
3. Adoption of the relevant provisions of Universal Declaration of Human Rights and International Covenant of Civil and Political Right by enacting necessary Legislations

4. Proper implementation of the existing law.

It is a well-known fact that Sri Lanka has sufficient law in protecting human rights, but due to the improper implementation of these laws has limited these laws only to a black letter document. Existing a strong political influence towards the law making authorities is the major reason for such improper implementation of law. Therefore, admiring the concept of Separation of Interest rather than merely establishing the concept of Separation of Power is needed.

5. Giving an equal standard to both public law and private law areas.

It may helpful to balance the protection of right to information and privacy rights by avoiding the conceptual barriers.

6. Making the law more close to people

Contemporarily, the historical nature of judicial system has created a considerable gap between the law and the society. It has let people think of obtaining a legal remedy for violation of their rights is a mere waste of their cost and time. Therefore, establishing a more confident judicial system is essential not only for minimize the distant relationship of people towards the law, but also it leaves room to broadly develop these legal concepts by upholding strong judgments for variety of circumstances. Accordingly, the rights would be decided on a case-by case basis with a view toward the relative importance of various interests.

7. Strengthening public awareness towards law, human rights and current political movements.

Although ignorance of law is not considered as a defense, the field survey of this research clearly revealed that most people have not sufficient idea with regard to the current legal system, human right standards and political movement. The difficult language of legal documents can be taken as one key issue for that. With regard to this, it appears that mass media can play a major role on that. Here, rather than providing incidents for their mere population, bringing most important legal and political facts to the society is very important. In addition to that, organizing public awareness programs, conference and campaigns, as well as distributing leaflet, etc. by human right activist group to increase public awareness on current law, political and human right movements is also admirable. 


\section{Conclusion}

Many international Human Rights instruments like Universal Declaration on Human Rights and International Covenant on Civil and Political Rights recognize right to information and right to privacy as a couple of rights with equal importance. Moreover, many developed and developing countries have been imposed constitutional safeguards to protect them. People around the world have united as civil organizations such as American Civil liberties Union and National Campaign on People's Right to Information to strengthen these rights.

However, awareness of people and state officers in Sri Lanka with this regard seems to be at a very low level. Consequently, political and legal experts have a responsibility to educate public on the prominence of these two rights as basic human rights. A parliament policy needs to be composed elaborating a comprehensive mechanism to empower these rights.

It is needless to mention that, before balancing the protection of right to privacy and right to information, it should be properly protected in the country. Taking measures only to protect only right to information not only downgrade the essentiality of establishing right to privacy, but also it completely destroys the balance of both rights. Therefore, on the whole, it emphasize my hypothesis that Sri Lankan legal system has not succeeded in balancing the protection of right to privacy and right to information. Accordingly, Sri Lankan legal tradition needs to be revised by expressly incorporating right to privacy to the supreme law of the country, and makes people aware about these rights and their importance.

\section{References}

Access to Information Act (Canada) (1985).

American Convention on Human Rights (ACHR) (1969).

Banisar, D. (2011). Right to Information and Privacy: Balancing Rights and Managing Conflicts. Retrieved March 16, 2017, from https://www.ip-rs. si/fileadmin/user_upload/Pdf/Publikacije_ostalih_pooblascencev/Right_ to_Information_and_Privacy_banisar.pdf

Channa Pieris v. AG, 1 SLR 1 (Supreme Court of Sri Lanka 1994).

Coeriel and Aurik v. Netherlands, Communication No. 453 (Human Rights Commitee 1991).

Constitution of the Democratic Socialist Republic of Sri Lanka (1978).

Environmental Foundation vs UDA, SC(FR)Application No.47/04:SCM (Supreme Court of Sri Lanka 2005). 
Establishments Code of Sri Lanka (1977).

European Convention for the Protection of Human Rights and Fundamental Freedoms (1950).

Fernando Vs. Sri Lanka Broadcasting Corporation [SLBC], 1 SLR 157 (Supreme Court of Sri Lanka 1996).

International Covenant of Civil and Political Rights (ICCPR) Act No 56 (2007).

International Covenant on Civil and Political Rights (1976).

Jayamanne, N. (n.d.). Freedom of Expression and Right to Information.

Jayawickrama, N. (2002). The Judicial Application of Human Rights Law; National, Regional and International Jurisprudence (1 ed.). Cambridge University Press.

Kharak Singh v. State of Uttar Pradesh, 1 SCR 332 (Supreme Court of India 1964).

Nadaraja v. Obeysekara, 76 NLR 268 (Supreme Court of Sri Lanka 1976).

Ninteenth Amendment to the Constitution (2015).

Perera, S. (2016, 2017 March). Right to Information Act No 12 of 2016 of Sri Lanka. Retrieved 16, from Lawyer Issue: httpwww.lawyerissue.comtheright-to-information-act-no-12-of-2016-of-sri-lanka

Privacy Act (Canada) (1985).

Right to Information Act (India) (2005).

Right to Information Act no 12 (2016).

Sarvananthan, M. (2016, June 10). The Right to Information Act and the Road Ahead. Retrieved March 16, 2017, from Colombo Telegraph: https:// www.colombotelegraph.com/index.php/the-right-to-information-act-itsdiscontents/

Sri Lanka Press Council Law No. 5 (1973).

Sri Lankan Brief. (2015). Beyond Right to Information towards the Open Government in Sri Lanka. Retrieved March 16, 2017, from http:// srilankabrief.org/2015/03/beyond-rti-towards-open-government-in-srilanka/

Sri Lankan Brief. (2016). Sri Lankan RTI Law Became World's Third Best. Retrieved March 16, 2017, from http://srilankabrief.org/2017/02/srilanka-rti-laws-become-worlds-third-best/ 
Sri Lankan View. (2016). Right to Informaion, Standards, Laws and Rights. Retrieved March 16, 2017, from http://english.lankaviews.com/right-toinformation-standards-laws-and-reality/

Sunila Abesekara v. Ariya Rubasinghe, 1 SLR 314 (Supreme Court of Sri Lanka 2000).

UN Commission. (1995). 2 UN Doc. E/CN.4/1995/32, .

Universal Declaration of Human Rights (UDHR) (1948).

Victor Ivon v. Sarath N. Silva, 1 Sri LR 340 (Supreme Court of Sri Lanka 1998).

Warren , \& Brandeis. (1890). The Right to Privacy. Olmstead: Harvard Law Review.

Wickramaratne, J. (2007). Fundemental Rights in Sri Lanka (2 ed.). Pannipitiya: Stamford Lake (Pvt) Ltd.

\section{End Notes}

1. (UN Commission, 1995)

2. (Sri Lankan View, 2016)

3. (Sarvananthan, 2016)

4. (Jayamanne)

5. (Warren \& Brandeis, 1890)

6. Jayawickrama, 2002)

7. (Universal Declaration of Human Rights (UDHR), 1948) S. 12

8. (International Covenant on Civil and Political Rights, 1976) S. 17

9. (European Convention for the Protection of Human Rights and Fundamental Freedoms, 1950) s. 8

10. (American Convention on Human Rights (ACHR), 1969) s. 11

11. (Coeriel and Aurik v. Netherlands, 1991)

12. (Banisar, 2011) 
13. (Banisar, 2011)

14. (Constitution of the Democratic Socialist Republic of Sri Lanka, 1978)

15. (Ninteenth Amendment to the Constitution, 2015) Article 14A

16. (Right to Information Act no 12, 2016)

17. (Right to Information Act no 12,2016$)$ s. 3

18. (Right to Information Act no 12,2016 ) s. 4

19. (Sri Lankan Brief, Sri Lankan RTI Law Became World's Third Best, 2016)

20 (Right to Information Act no 12,2016$)$ s. 5(1)a

21. (Right to Information Act no 12,2016$)$ s. 5(1)e

22. (Right to Information Act no 12,2016$)$ s. 6

23. (Fernando Vs. Sri Lanka Broadcasting Corporation [SLBC], 1996)

24. (Channa Pieris v. AG, 1994)

25. (Environmental Foundation vs UDA, 2005)

26. (Nadaraja v. Obeysekara, 1976)

27. (Universal Declaration of Human Rights (UDHR), 1948) S. 12

28. (International Covenant on Civil and Political Rights, 1976) s. 17

29. (Constitution of the Democratic Socialist Republic of Sri Lanka, 1978) s. 27(12)

30. (Establishments Code of Sri Lanka , 1977)

31. (Sri Lanka Press Council Law No. 5 , 1973)

32. (Access to Information Act (Canada), 1985)

33. (Privacy Act (Canada), 1985)

34. (Right to Information Act (India), 2005)

35. (Perera, 2016)

36. (Sri Lankan Brief, Beyond Right to Information towards the Open Government in Sri Lanka, 2015)

37. (Perera, 2016)

38. (Victor Ivon v. Sarath N. Silva, 1998)

39. (Sunila Abesekara v. Ariya Rubasinghe, 2000)

40. (Kharak Singh v. State of Uttar Pradesh, 1964)

41. (Constitution of the Democratic Socialist Republic of Sri Lanka, 1978) S. 29 
42. (International Covenant of Civil and Political Rights (ICCPR) Act No $56,2007)$

43. (European Convention for the Protection of Human Rights and Fundamental Freedoms, 1950) s. 10(1)

44. (Fernando Vs. Sri Lanka Broadcasting Corporation [SLBC], 1996)

45. (Jayawickrama, 2002)

46. (Wickramaratne, 2007) p. 615

47. (Wickramaratne, 2007) p. 615 